OPEN ACCESS

Edited by:

Steven Templeton,

Indiana University School of Medicine - Terre Haute,

United States

Reviewed by: Michael K. Mansour,

Massachusetts General Hospital, United States

Michail Lionakis,

National Institute of Allergy and Infectious Diseases, United States

*Correspondence:

Neil A. R. Gow

n.gow@abdn.ac.uk

tThese authors have contributed equally to this work.

Specialty section: This article was submitted to Microbial Immunology, a section of the journal Frontiers in Immunology

Received: 10 March 2017 Accepted: 12 May 2017

Published: 07 June 2017

Citation:

Mukaremera L, Lee KK, MoraMontes HM and Gow NAR (2017) Candida albicans Yeast,

Pseudohyphal, and Hyphal Morphogenesis Differentially Affects Immune Recognition.

Front. Immunol. 8:629. doi: 10.3389/fimmu.2017.00629

\section{Candida albicans Yeast, Pseudohyphal, and Hyphal Morphogenesis Differentially Affects Immune Recognition}

\author{
Liliane Mukaremera ${ }^{1,2 \dagger}$, Keunsook K. Lee ${ }^{1 \dagger}$, Hector M. Mora-Montes ${ }^{3}$ and Neil A. R. Gow ${ }^{1 *}$ \\ ${ }^{1}$ Aberdeen Fungal Group, Institute of Medical Sciences, Foresterhill, University of Aberdeen, Aberdeen, United Kingdom, \\ ${ }^{2}$ Department of Microbiology and Immunology, Medical School, University of Minnesota, Minneapolis, MN, United States, \\ ${ }^{3}$ Departamento de Biología, División de Ciencias Naturales y Exactas, Universidad de Guanajuato, Guanajuato, Mexico
}

Candida albicans is a human opportunist pathogen that can grow as yeast, pseudohyphae, or true hyphae in vitro and in vivo, depending on environmental conditions. Reversible cellular morphogenesis is an important virulence factor that facilitates invasion of host tissues, escape from phagocytes, and dissemination in the blood stream. The innate immune system is the first line of defense against $C$. albicans infections and is influenced by recognition of wall components that vary in composition in different morphological forms. However, the relationship between cellular morphogenesis and immune recognition of this fungus is not fully understood. We therefore studied various vegetative cell types of $C$. albicans, singly and in combination, to assess the consequences of cellular morphogenesis on selected immune cytokine outputs from human monocytes. Hyphae stimulated proportionally lower levels of certain cytokines from monocytes per unit of cell surface area than yeast cells, but did not suppress cytokine response when copresented with yeast cells. Pseudohyphal cells induced intermediate cytokine responses. Yeast monomorphic mutants had elevated cytokine responses under conditions that otherwise supported filamentous growth and mutants of yeast and hyphal cells that were defective in cell wall mannosylation or lacking certain hypha-specific cell wall proteins could variably unmask or deplete the surface of immunostimulatory ligands. These observations underline the critical importance of $C$. albicans morphology and morphology-associated changes in the cell wall composition that affect both immune recognition and pathogenesis.

Keywords: Candida albicans, cell wall, cytokine, immune recognition, morphogenesis

\section{INTRODUCTION}

Fungal pathogens are associated with a wide range of human diseases from superficial infections of the skin and mucosal surfaces to life-threatening systemic infections, depending on host health and immunocompetence. Candida species account collectively for as many as 400,000 cases of systemic fungal disease with associated mortality rates of up to $40 \%(1-4)$. Of these species, Candida albicans is the most common agent of disease and is characterized by its morphological plasticity. It is capable of vegetative growth in vitro and in vivo as ovoid budding yeast-like cells and as branching filamentous cells that exist as more or less elongated and constricted chains of yeast cells called pseudohyphae 
or parallel-sided hyphal cells (5-10). Other cell types, such as GUT, gray, and opaque cells, are a tristable system of specialized cells involved in colonization of specific body sites and in mating competence (10). We set out to characterize differences in the immune response by human peripheral blood mononuclear cells (PBMCs) to yeast cells, hyphae, and pseudohyphae as the three major morphological forms of C. albicans.

The innate immune system is the first line of defense against all invading organisms and plays a major role in resistance to infectious diseases in immunocompetent hosts (11). Phagocytes detect microbial pathogen-associated molecular patterns (PAMPs) via pattern-recognition receptors (PRRs), resulting in signalingmediated transcription and secretion of inflammatory mediators, such as chemokines and cytokines that recruit neutrophils and other immune cells to the site of infection, resulting in localized killing of the pathogen and activation of the adaptive immune response (11-13).

C. albicans PAMPs that activate the inflammatory response are located in both the outer and inner layers of the intact cell wall $(4,11,14-16)$. Mannans and glucans are the main elicitors of both cytokine production and phagocytosis and are recognized by a range of C-type lectins and toll-like receptors (TLRs) (4, 17-21). The O-linked mannans are sensed through the TLR4 receptor (17), $\beta$-mannan is recognized by galectin-3 (22-25), and $\alpha$-linked $N$-mannans are recognized by the mannose receptor (MR), dectin-2, mincle, and DC-SIGN $(21,26)$. Opsonized $\beta 1,6$-glucan acts as an immune agonist (27), and chitin is taken up by the MR and induces TLR9- and NOD2-dependent IL-10 production $(4,28)$.

Most immune recognition studies have focused on C. albicans yeast cells as the cell target; however, it is known that filamentous hyphal cells induce an altered immune response $(4,6,8,21$, 29-32). The switch between yeast and hyphal growth is critical for virulence $(6,8,33,34)$, affecting numerous properties including the expression of morphology-dependent cell wall adhesins, invasins, proteases, and a raft of other phenotypic and biochemical properties, including the recently discovered candidalysin toxin (35). Mutants locked in either the yeast or hypha form are avirulent, suggesting that the ability to transit reversibly between these morphotypes potentiate the virulence of this fungus $(7,33$, 35-40). Pseudohyphae are a distinct growth form that differs from both yeast cells and parallel-sided hyphae and are characterized by synchronously dividing elongated yeast cells $(5,7,41,42)$. Although pseudohyphal forms are generated by a wide range of Candida species, we know little about the immune response to pseudohyphal cells.

It is therefore important to understand the consequences of cellular morphogenesis of $C$. albicans on immune recognition and the activation of inflammation. Here, we demonstrate that C. albicans hyphae stimulated lower levels of cytokine production from human PBMCs than did yeast cells, but did not suppress the immune response of yeast cells in trans. Pseudohyphae elicited intermediate cytokine profiles between those of yeast and hyphae and again did not suppress yeast-induced cytokines. We also demonstrate that cell wall mannosylation and certain hypha-specific cell wall proteins affect morphology-dependent recognition by $\mathrm{PBMCs}$.

\section{MATERIALS AND METHODS}

\section{Strains, Media, and Culture Conditions Inducing Cellular Morphogenesis}

Strains used in this work are listed in Table S1 in Supplementary Material. Cells were maintained and propagated at $30^{\circ} \mathrm{C}$ in either Sabouraud broth $[1 \%(\mathrm{w} / \mathrm{v})$ mycological peptone, $4 \%$ $(\mathrm{w} / \mathrm{v})$ glucose] or YPD broth [1\% (w/v) yeast extract, $2 \%(\mathrm{w} / \mathrm{v})$ mycological peptone, $2 \%(\mathrm{w} / \mathrm{v})$ glucose]. The immune reposes to hyphae induced by multiple independent growth conditions were compared. Hyphae were generated using multiple independent methods: (i) $20 \%$ (v/v) fetal calf serum (FCS) or in RPMI 1640 supplemented with $2.5 \%$ (v/v) FCS, (ii) in YPD broth supplemented with $20 \%(\mathrm{v} / \mathrm{v}) \mathrm{FCS}$, (iii) in SC broth $[0.68 \%(\mathrm{w} / \mathrm{v})$ yeast nitrogen base without amino acids, $0.074 \%(\mathrm{w} / \mathrm{v})$ amino acids buffered with $0.378 \%(\mathrm{w} / \mathrm{v})$ PIPES] supplemented with $0.012 \%(\mathrm{w} / \mathrm{v})$ fresh $\mathrm{N}$-acetylglucosamine (GlcNAc), or (iv) in Lee's medium (43). Cultures were collected for use when greater 90-95\% filamentation was obtained (typically after $3.5 \mathrm{~h}$ of incubation at $37^{\circ} \mathrm{C}$ ). Hyphae were then washed twice in PBS and stored frozen at $-20^{\circ} \mathrm{C}$ until used in cytokine induction experiments.

C. albicans pseudohyphae were produced using conditions published previously with modifications (41). Overnight cultures of $C$. albicans were collected by centrifugation, washed twice with $0.15 \mathrm{M} \mathrm{NaCl}$, resuspended in $0.15 \mathrm{M} \mathrm{NaCl}$, and incubated at room temperature for $24 \mathrm{~h}$ to induce starvation. After 24 -h starvation, cells were inoculated into RPMI 1640 at a final concentration of $1 \times 10^{6}$ cells $/ \mathrm{ml}$ and incubated at 25,30 , or $37^{\circ} \mathrm{C}$ with shaking for $6 \mathrm{~h}$. Under these conditions, the vegetative morphology could be regulated by growth temperature alone, with yeast cells formed at $25^{\circ} \mathrm{C}$, pseudohyphae at $30^{\circ} \mathrm{C}$, and true hyphae at $37^{\circ} \mathrm{C}$. Heatkilled (HK) cells were prepared after incubation at $56^{\circ} \mathrm{C}$ for $1 \mathrm{~h}$, with killing verified by plating on YPD.

Samples of cells were fixed in 5\% (v/v) formalin for morphological and microscopical analyses. All photomicrographs were taken on an Olympus BX50 outfitted with an Infinity 1 digital camera. Morphology indices, which are a measure of the extent of cellular elongation and hence discrimination of constricted pseudohyphae from parallel-sided hyphae, were determined as published (41). All measurements were made using the measurement tool in ImageJ $1.47 \mathrm{v}$ (http://imagej.nih.gov/ij), and MIs were calculated in Microsoft Excel.

\section{Calculation of the Surface Area (SA) of Fungal Cells}

The SA of all cells was based on microscopical measurements made from DIC images using a Zeiss Axioplan 2 microscope and captured by a Hamamatsu C4742-95 digital camera (Hamamatsu Photonics, Hamamatsu, Japan). All measurements created by ImageJ were exported in Microsoft Excel. The SA of yeast cells was calculated based on measurements of the radius calculated from the average of the largest and smallest cell diameters of yeast cells $\left(4 \pi r^{2}\right)$. Germ tube SA was taken as the SA of the mother yeast plus the SA of the daughter germ tube (true hypha). Hypha SA based on SA $\left(2 \pi r^{2}+2 \pi r l\right)$ where the germ tube length $(l)$ was measured from the base of the mother cell and the germ tube diameter was the average 
of the narrowest and widest diameter measurements made along each germ tube. At least 50 measurements, and 3-4 biological replicates, of SA of individual yeast and hyphal cells grown were made.

\section{Cytokine Stimulation Assays}

Blood samples were collected from healthy volunteers according to local guidelines and regulations, as approved by the College Ethics Review Board of the University of Aberdeen (CERB/2012/11/676). The PBMCs were used in this study and isolated using Ficoll-Paque ${ }^{\text {TM }}$ PLUS (GE Healthcare) as previously described (44), with slight modifications. Unless otherwise indicated, $5 \times 10^{5}$ PBMCs in $100 \mu$ l were incubated in a round-bottom 96-well plate (Nunc) with $100 \mu \mathrm{l}$ of fungal cells at $1 \times 10^{6}$ cells/ $\mathrm{ml}$. After incubation for $24 \mathrm{~h}$ at $37^{\circ} \mathrm{C}$ under $5 \%(\mathrm{v} / \mathrm{v}) \mathrm{CO}_{2}$, plates were centrifuged at $1,000 \mathrm{~g}$ for $10 \mathrm{~min}$ at room temperature, and supernatants were saved and kept at $-20^{\circ} \mathrm{C}$ until use. For cytokine assays using mixed C. albicans cell types, PBMCs were first preincubated with $50 \mu \mathrm{l}$ of cells of one morphology at $2 \times 10^{6}$ cells/ $\mathrm{ml}$ for $1 \mathrm{~h}$ at $37^{\circ} \mathrm{C}$ under $5 \%(\mathrm{v} / \mathrm{v}) \mathrm{CO}_{2}$. Subsequently, $50 \mu \mathrm{l}$ of a sample containing a second sample of yeast or hyphae cells at $2 \times 10^{6} \mathrm{cells} / \mathrm{ml}$ were added to PBMCs. Plates were then incubated for a further $24 \mathrm{~h}$ at $37^{\circ} \mathrm{C}$, before supernatant collection and assay of induced cytokines. In experiments with PBMCs, the inoculum of hyphal cells was more or less aggregated. To assess the effect of cell aggregates on the cytokine stimulation, control experiments where hyphae were dispersed by ultrasonication before interaction with immune cells were performed, but theses did not show any significant differences with cultures of non-sonicated cells (data not shown). Therefore, steric blocking of monocyte access to fungal material did not explain the reduced response to hyphae that was observed.

TNF $\alpha$, IL- $1 \alpha$, IL- $1 \beta$, IL- 6 , and IL-10 concentrations were determined from coculture supernatants. For IL-1 $\alpha$ quantification, stimulated PBMCs were disrupted by three sequential temperature shock cycles, and homogenates used for cytokine determination. All cytokine concentrations were determined using enzyme-linked immunosorbent assays (R\&D Systems) according to the manufacturer's instructions.

\section{Cell Wall Extraction and Analysis}

C. albicans cells of different morphology were prepared as described above. Cells were collected by low-speed centrifugation and washed with ultrapure water, then broken using glass beads and a FastPrep machine (Qbiogene), homogenates were centrifuged at 13,000 $\mathrm{g}$ for $3 \mathrm{~min}$, and pellets, containing the cell debris and walls, were washed five times with $1 \mathrm{M} \mathrm{NaCl}$, resuspended in cell wall extraction buffer [50 mM Tris- $\mathrm{HCl}$ buffer $\mathrm{pH} 7.5,2 \%$ (w/v) SDS, $0.3 \mathrm{M} \beta$-mercaptoethanol, and $1 \mathrm{mM}$ EDTA], then boiled for $10 \mathrm{~min}$, and washed three times with ultrapure water. Cell walls were freeze dried and stored at $-20^{\circ} \mathrm{C}$ until used. The $\beta$-glucan, mannan, and chitin contents of cell wall preparations were determined by acid hydrolysis of the polymers and quantification of glucose, mannose, and glucosamine. Freeze-dried cell walls were hydrolyzed with $2 \mathrm{M}$ trifluoroacetic acid as described previously (45), and acid hydrolyzates were analyzed by HPAECPAD (high-performance anion-exchange chromatography with pulsed amperometric detection) (46).

\section{hPBMC Cell Damage Assay}

Human PBMC damage was assessed by lactate dehydrogenase (LDH) released into the supernatant in the culture medium. After 24 h stimulation with C. albicans either heat-killed yeast (HKY) or HKH over a range of MOIs (Candida cells:hPBMCs) from $0.002: 1$ to $2: 1$. The $\mathrm{LDH}$ release was determined using the cytotoxicity detection kit (Roche Applied Science), according to the manufacturer's instructions. As a negative control for LDH release, $5 \times 10^{5}$ cells of hPBMCs were incubated with only the cell culture medium and incubated at $37^{\circ} \mathrm{C}$ with $5 \% \mathrm{CO}_{2}$ for $24 \mathrm{~h}$. For the positive control maximum $\mathrm{LDH}$ release, $5 \times 10^{5}$ cells of hPBMCs was obtained by treatment with $2 \%$ Triton X-100 and incubated under the same conditions. The percentage of $\mathrm{LDH}$ release was calculated relative to the value for $100 \%$ cell death.

\section{Statistical Analyses}

The Mann-Whitney $U$ test, $t$-test, or one-way ANOVA with a Dunnett's post hoc test in an appropriate parameter was used to analyze data. Results are presented as means \pm SDs or SEMs and levels of significance determined at $p<0.05$.

\section{RESULTS}

\section{Differential Cytokine Induction by Yeast and Filamentous Cell Types}

We used the cytokine response of human PBMCs as a read out to investigate the role of $C$. albicans morphogenesis on immune recognition. The cytokine profile of human PBMCs was compared when these immune cells were exposed to yeast cells and filamentous forms (true hyphae and pseudohyphae) of C. albicans. Yeast, pseudohyphal, and hyphal cells could all be induced in vitro using various culture conditions that preferentially stimulated a specific C. albicans cell morphology. Live and HK cells of different cell morphologies were also analyzed in our study. Across a wide range of conditions, heat killing increased the total amount of $\mathrm{TNF} \alpha$ and other cytokines induced by yeast cells, and to a lesser extent, filamentous cells (Figure 1), suggesting that heat-treatment unmasks cytokine inducing PAMPs due to thermal disruption of components of the outer layer of the cell wall, thus exposing internal cytokine inductive cell layers to PRRs found on the surface of human PBMCs.

Under the conditions employed, more than $99 \%$ of yeast cells were obtained at $25^{\circ} \mathrm{C}$ and more than $94 \%$ of hyphae with at least two cell compartments were generated at $37^{\circ} \mathrm{C}$ (data not shown). Cell for cell, HK yeast cells induced significantly more TNF $\alpha$ than hyphal cells (Figure 1A). Germ tubes/hyphae induced less TNF $\alpha$ despite the presence of the parent yeast cell, implying that hypha formation may suppress TNF $\alpha$ production that would be normally associated with the cell surface of HK yeast cells (Figures 1A-C and 3).

TNF $\alpha$ production induced by C. albicans was dose dependent (Figure 1B). Live yeast cells stimulated lower cytokine production compared to HK yeast cells-a difference that was less apparent when comparing live and HK true hyphal cells (Figure 1B). Both live and $\mathrm{HK}$ hyphae stimulated poor TNF $\alpha$ production compared to that of $\mathrm{HK}$ yeast cells (Figures $\mathbf{1 B}, \mathbf{C}$ ). In addition, $\mathrm{LDH}$ activity 


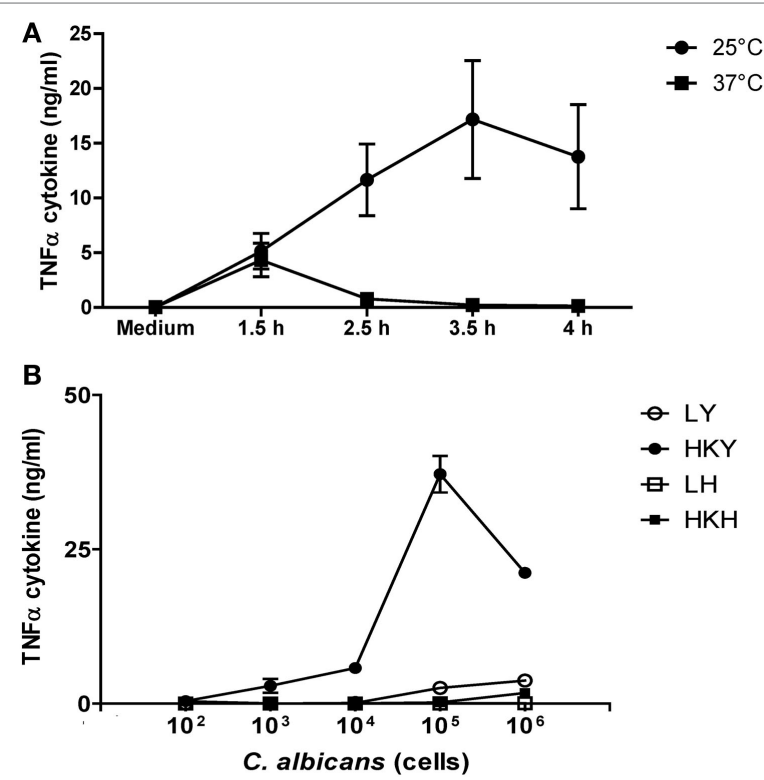

$\circ$

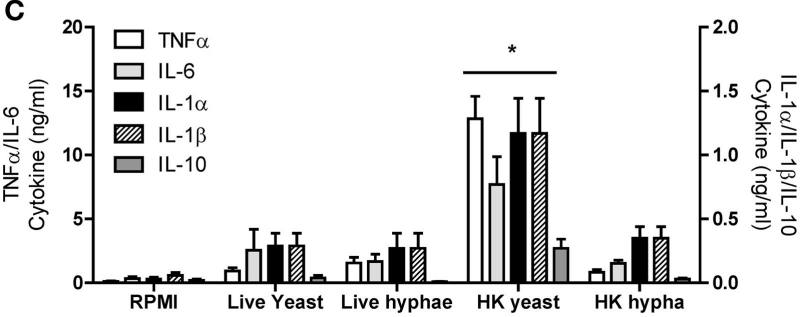

FIGURE 1 | TNF $\alpha$ stimulation with Candida albicans yeast and hyphal cells by human peripheral blood mononuclear cells (PBMCs).

(A) Cytokine production by human PBMCs stimulated with yeasts cells $(Y)$ of C. albicans NGY152 grown at $25^{\circ} \mathrm{C}$ (closed circles) or hyphae $(\mathrm{H})$ grown at $37^{\circ} \mathrm{C}$ (closed squares) in RPMl $1640+2.5 \%$ fetal calf serum (FCS). Error bars $=$ SEM $(n=3)$. (B) Dose-dependent stimulation of TNF $\alpha$ production by human PBMCs when stimulated with different forms of C. albicans NGY152 grown in RPMI 1640 + 2.5\% FCS. Heat-killed yeasts (HKY), closed circles; live yeasts (LY), open circles; HK hyphae $(H K H)$, closed squares; live hyphae $(\mathrm{LH})$, open squares. Error bars $=\operatorname{SEM}(n=6)$. In these experiments, a total of $5 \times 10^{5}$ PBMCs were used in each treatment and so the $\mathrm{MOI}$ varied from $0.0002: 1$ to $2: 1$. (C) Cytokine production by human PBMCs stimulated with the different morphological forms of $C$. albicans NGY152. In each treatment, an inoculum of $1 \times 10^{6}$ cells $/ \mathrm{ml}$ was used. Results are means $\pm \operatorname{SEM}(n=6$; $\left.{ }^{\star} p<0.05\right)$.

released into the supernatant was measured after $24 \mathrm{~h}$ stimulation with C. albicans HKY or HKH. There was no significant difference between C. albicans stimulated and non-stimulated hPBMCs (Figure S1 in Supplementary Material). Therefore, although TNF $\alpha$ production by hPBMCs incubated with $1 \times 10^{6}$ cells of HKY was significantly reduced, this was not due a loss of viability of hPBMCs. Similar results were obtained for a range of other cytokines, including IL-1 $\alpha$, IL-1 $\beta$, IL-6, and IL-10 (Figure 1C).

We next investigated how hypha cell SA correlated with TNF $\alpha$ production by human PBMCs. Cell SA and cell size (diameter or length) of C. albicans yeast and hyphae were calculated assuming yeast cells were elliptical spheres, and germ tubes were parallelsided cylinders. The size and SA of yeast plus associated germ

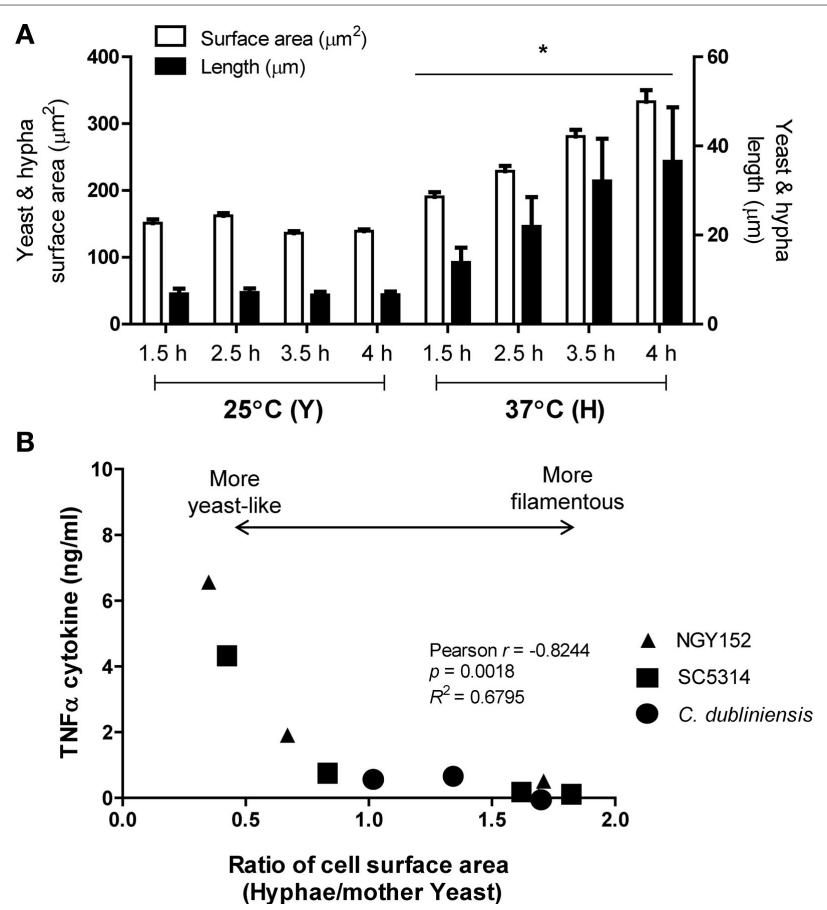

FIGURE 2 | Cell surface area (SA) of hyphal forming cells negatively correlated with TNF $\boldsymbol{\alpha}$ stimulation. (A) Cell SA and cell size of Candida albicans SC5314 yeast $(\mathrm{Y})$ or hyphae $(\mathrm{H})$ grown at either 25 or $37^{\circ} \mathrm{C}$ for 1.5 , $2.5,3.5$, and $4 \mathrm{~h}\left({ }^{*} p<0.05\right)$. Error bars are SEM $(n>50$ individual cells). (B) Relationship between TNF $\alpha$ production and extent of cell elongation expressed as the ratio of the hyphal cell area and the mother yeast cell area for C. albicans SC5314 and NGY152, and Candida dubliniensis CD36.

tubes cells grown at 25 and $37^{\circ} \mathrm{C}$ are shown in Figure 2A. SA and length of hyphae increased by time. Under these conditions (at $3.5 \mathrm{~h}$ ) of growth, yeasts had a mean diameter of $6.6 \pm 0.1 \mu \mathrm{m}$ $\left(\right.$ mean \pm SEM) and mean SA of $136 \pm 3.1 \mu \mathrm{m}^{2}$, respectively (Figure 2A). Hyphae had approximately twofold increased SA and were fivefold longer than the yeast cell diameter at the time cells were harvested. These values are comparable with those in previous reports (47). The average growth rate of hyphae grown in RPMI1640 plus $2.5 \%$ serum was $9.0 \pm 1.1 \mu \mathrm{m} / \mathrm{h}$. For C. albicans strains SC5314, NGY152, and the hypha-forming species Candida dubliniensis (strain CD36), there was a negative correlation between hypha to yeast cell surface ratio and $\mathrm{TNF} \alpha$ production by human PBMCs (Figure 2B). Longer hyphae induced progressively less TNF $\alpha$ production per unit of cell surface (data not shown). We conclude that hyphae induce less TNF $\alpha$ than yeast cells and that the hypha surface may in some way suppress TNF $\alpha$ production by the cell wall of the attached parent yeast cell or that the yeast cell wall may be modified during the process of germ tube formation, so that it becomes less inductive of cytokine formation.

\section{Hypha Formation and Cytokine Induction by Human PBMCs}

In order to confirm whether this observation was indeed related to cell morphology rather than the growth conditions used to 
generate yeast and hyphae, we compared the immune response of hyphae generated in different growth media. Live and HK hyphae generated in either YPD medium supplement with FCS, Lee's medium, minimal medium (SC) added with GlcNAc, or in dilute FCS, were universally poorer inducers of TNF $\alpha$, IL- $1 \alpha$, IL-1 $\beta$, IL-6, and IL-10 (Table S1 in Supplementary Material) than yeast cells. Therefore, the reduced ability of C. albicans hyphae to

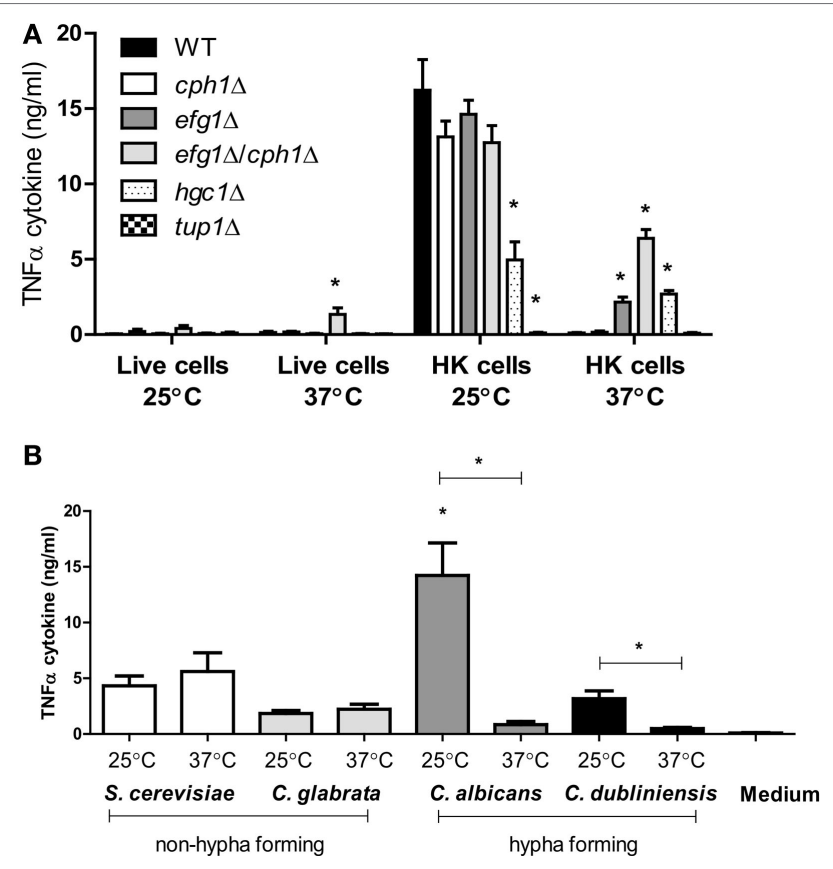

FIGURE 3 | TNF $\alpha$ production by human peripheral blood mononuclear cells stimulated with morphological mutants of Candida albicans mutants or other yeast species. (A) C. albicans NGY152 (WT), JKC19

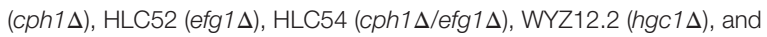
Bca2-10 (tup1 $\Delta$ ). Results are means \pm SEM $\left(n=6\right.$; $\left.{ }^{*} p<0.05\right)$. (B) TNF $\alpha$ stimulation by non-hypha-forming species Saccharomyces cerevisiae (S288C) and Candida glabrata (ATCC 2001) compared to hypha-forming species C. albicans (NGY152) and Candida dubliniensis (CD36) $\left({ }^{*} p<0.05\right)$. Error bars $=\operatorname{SEM}(n=9)$. stimulate cytokine production was independent of the hyphalinducing growth conditions used.

Next, we investigated the TNF $\alpha$ simulation by yeast cells of Candida glabrata and Saccharomyces cerevisiae (48), which, unlike C. albicans and C. dubliniensis, are not able to form hyphae or pseudohyphae. Yeast cells of $S$. cerevisiae, C. glabrata, and C. dubliniensis stimulated comparable levels of TNF $\alpha$ cytokine when grown at 25 and $37^{\circ} \mathrm{C}$ (Figure 3B). C. dubliniensis yeast cells induced less $\mathrm{TNF} \alpha$ than C. albicans, when grown at $25^{\circ} \mathrm{C}$. However, as with C. albicans, C. dubliniensis yeast grown at $25^{\circ} \mathrm{C}$ induced more cytokine than hyphae grown at $37^{\circ} \mathrm{C}$. Therefore, the hyphae of both C. albicans and C. dubliniensis stimulated less $\mathrm{TNF} \alpha$ than the respective yeast form.

We then assessed the ability of various mutants that regulate morphogenesis to stimulate cytokine production. The cph $1 \Delta$ mutant was still able to form hyphae under the experimental conditions used (93\% hypha production), and these cells did not stimulate a high level of TNF $\alpha$ by human PBMCs (Figure 3A). In comparison, the efg $1 \Delta$ mutant mainly produced pseudohyphae (more than 90\%) and stimulated only about $15 \%$ of TNF $\alpha$ of the control HK wild-type yeast cells. The $c p h 1 \Delta /$ efg $1 \Delta$ double mutant was unable to form hyphae at $37^{\circ} \mathrm{C}$ and stimulated significantly higher amounts of $\mathrm{TNF} \alpha$ at $37^{\circ} \mathrm{C}$ than the hyphal wild-type parent (Figure 3A). Another yeast-locked $h g c 1 \Delta$ mutant also induced higher levels of $\mathrm{TNF} \alpha$ at $37^{\circ} \mathrm{C}$, although surprisingly this was also reduced at $25^{\circ} \mathrm{C}$, indicating that $\mathrm{Hgcl}$ influences TNF $\alpha$ stimulation in human PBMCs for both yeast and hyphae. By contrast, the pseudohypha-locked tup $1 \Delta$ mutant stimulated a poor cytokine production at both 25 and $37^{\circ} \mathrm{C}$ (Figure 3A). Similar results for TNF $\alpha$ were observed for IL- $1 \alpha$, IL- $1 \beta$, IL-6, and IL-10 (data not shown).

Next, we investigated the apparent ability of the germ tube to inhibit the ability of the mother yeast cells to stimulate TNF $\alpha$ cytokine production. PBMCs were pretreated with live or HK yeast or hyphae for $1 \mathrm{~h}$, then a second stimulus of the same or another morphotype was added. PBMCs preincubated with HK yeast cells and then stimulated with either live or HK hyphae were not compromised in their ability to produce $\mathrm{TNF} \alpha$ (Figure 4). Reciprocally when HK hyphae were preincubated with PBMCs

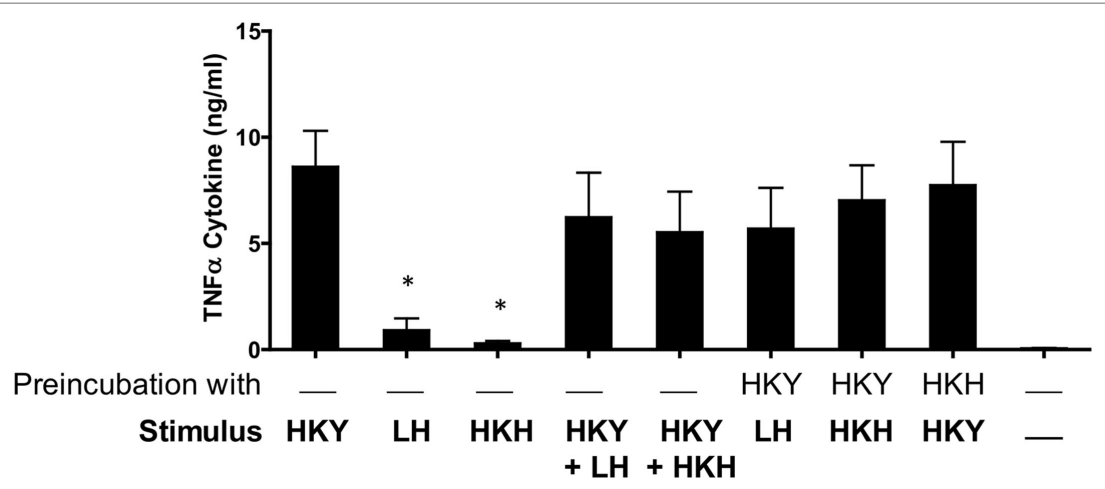

FIGURE 4 | Stimulation of cytokine production by human peripheral blood mononuclear cells (PBMCs) interacting with Candida albicans yeast cells and hyphae. Human PBMCs in RPMI 1640 were preincubated $1 \mathrm{~h}$ with either C. albicans NGY152 yeast cells or hyphae and then stimulated with a second cell type for 24 h. HKY, heat-killed yeast; LH, live hyphae; HKH, heat-killed hyphae ( ${ }^{*} p<0.05 ; n=12$ ). 
and then stimulated with HK yeast cells, there was a no significant reduction in the cytokine response (Figure 4). When yeast cells and hyphae were mixed together in a ratio 1:1, there was a strong cytokine production comparable to that elicited with HK yeast cells alone. Therefore, germ tubes with an attached parent yeast cell did not induce a response that would normally be associated with free yeast cells; however, hyphae did not block cytokine stimulation by yeast cells presented in trans.

The possibility that $C$. albicans reduced cytokine production by hyphae was due to blocking receptors on immune cells was tested by coincubating hyphal cells with various TLR ligands including $\mathrm{Pam}_{3} \mathrm{CSk}_{4}$, LPS, zymosan, flagellin, and curdlan. However, C. albicans hyphae did not block nor reduce TNF $\alpha$, IL-1 $\beta$, or IL- $1 \alpha$ stimulated by these TLRs ligands used (Figure S2 in Supplementary Material).

\section{Cell Wall Composition and the Immune Response}

The fungal cell wall contains most of the PAMPs recognized by the innate immune cells $(4,11)$. Thus, we next assessed the ability of yeast and hyphal cells with specific cell wall defects to stimulate cytokine production by human PBMCs. A chs $3 \Delta$ null mutant with a low chitin content at the cell wall (49), and a $m n n 4 \Delta$ mutant (50) lacking cell wall mannosylphosphate, were unaffected in the PBMC-induced cytokine production, compared to wild-type control cells (Figure 5A). A pmr1s mutant (51), which is deficient in yeast and hyphal cell wall $\mathrm{N}$ - and $\mathrm{O}$-linked mannan, induced a reduced cytokine response by $\mathrm{HK}$ yeast cells, but an increased cytokines response from live and HK hyphae. This suggests that for yeast cells the lack of mannan reduced the overall immune response, while in hyphae the major effect of mannan depletion was to reveal subsurface immunostimulatory ligands such as $\beta$-glucan. In the $O$-mannosylation $m n t 1 / m n t 2 \Delta$ mutant (52), and the core $N$-mannan mns1 $\Delta$ mutant (45) the secretion of most cytokines was enhanced or not affected in yeast or hyphal cells. IL-1 $\alpha$ secretion from monocytes was enhanced to the greatest extend in the pmr $1 \Delta$, mnt $1 / m n t 2 \Delta$, and $m n s 1 \Delta$ mutants in both yeast and hyphal cells (Figure 5B).

We compared the cytokine levels produced by a number of mutants that lacked hypha-associated cell wall proteins including als $3 \Delta$ (53), hwp $1 \Delta$ (54), hyr1 $\Delta$ (55), and ece1 $\Delta$ (56) with those stimulated with wild-type control cells. Only the $h w p 1 \Delta$ HK mutant hyphae stimulated a higher cytokine production than wild-type control cells (Figure 5C). Unexpectedly, despite the hypha-specific expression pattern for HYR1 (55), the hyr $1 \Delta$ mutant yeast cells stimulated a slightly reduced cytokine response from human PBMCs compared to wild-type control cells (Figure 5C). The $h w p 1 \Delta$ mutant showed no significant differences in mannan, glucan, and chitin content of the cell wall, when compared to wild-type control cells in both morphologies (Table 1), suggesting that this proteins may act in masking cytokine stimulating PAMPs in the cell wall. By contrast, yeast and hyphal cells of the mns $1 \Delta$ and pmr $1 \Delta$ mutants displayed a significant reduction in cell wall mannan and increased levels of glucan (Table 1). Therefore, cell wall mannosylation and the presence of Hwp1 were important for the reduced ability of hyphae of C. albicans to induce cytokines by human PBMCs.
We also tested the effect of deletion of the yeast-specific gene PGA29 on cytokine production by human PBMCs and noted that this HK mutant induced less TNF $\alpha$ under conditions of yeast growth (Figure S3 in Supplementary Material). The reconstituted heterozygous pga29/PGA29 mutant restored the TNF $\alpha$ induction to normal levels. Therefore, morphology-specific cell wall proteins of both yeast and hyphae influenced immune recognition.

\section{C. albicans Pseudohyphae Stimulate Intermediate Cytokine Levels from Human PBMCs}

We then examined the ability of pseudohyphae to induce cytokine production. We deployed a method in which changes in temperature alone could generate yeast cells, pseudohyphae, or hyphae $(41,57)$. When C. albicans NGY152 was grown in RPMI 1640 medium at a neutral $\mathrm{pH}$ and at $30^{\circ} \mathrm{C}$ for $6 \mathrm{~h}$ (Figure 6A), it reproducibly resulted in a largely pseudohyphal population ( 90\%). For this strain, growth at $25^{\circ} \mathrm{C}$ yielded yeast cells $(\mathrm{MI}=0.65 \pm 0.06$, mean $\pm \mathrm{SEM}), 30^{\circ} \mathrm{C}$ yielded pseudohyphae $(\mathrm{MI}=2.34 \pm 0.19)$, and $37^{\circ} \mathrm{C}$ yielded hyphal forms $(\mathrm{MI}=8.65 \pm 0.73$ ) (Figure $6 \mathrm{~B})$.

Next, we investigated cytokine production of human PBMCs stimulated with pseudohyphae in comparison to yeast and hyphae. In a range of experiments pseudohyphal cell populations generated reproducibly intermediate levels of TNF $\alpha$ and other cytokines from live and HK cells, although the differences were not always significant at $p<0.05$ and the level of significance varied depending on whether the average MI of a given population of pseudohyphae was sufficiently distinct from that of populations of yeast cells or hyphae (Figures 6A-D). There was a statistically significant correlation between the level of TNF $\alpha$ and IL- $1 \beta$ cytokine from PBMCs and the MI of $C$. albicans cells inducing these cytokines (Figure 6E).

\section{DISCUSSION}

Multiple independent studies have proposed a positive correlation between the formation of $C$. albicans hyphae and an enhanced capacity for tissue invasion, damage, and virulence (6, $33,39)$. However, the significance of $C$. albicans morphogenesis on the innate immune response has not been fully characterized. Here, the interaction of yeasts, pseudohyphae, and hyphae of this fungus with cells of the human innate immune system was investigated using cytokine production by human PBMCs as an immunoassay readout. We demonstrate that yeast cells generated more inflammatory cytokines from PBMCs than hyphae, and that pseudohyphae generated intermediate cytokine levels. These differences were observed in independent strains for cells generated in different growth media. Heat killing of cells has been used frequently in immunological studies of C. albicans to prevent cells undergoing filamentation in response to serum components of cell culture media when exposing Candida to immune cells during cytokine induction assays $(58,59)$. HK cells had enhanced immune responses, which has been interpreted as being due to heat-induced permeabilization of the cell wall and subsequent exposure of the underlying $\beta 1,3$-glucan layer, which is strongly immunogenic (18). Our data support this hypothesis and suggest that HK cells generate a greater cytokine signal because more 


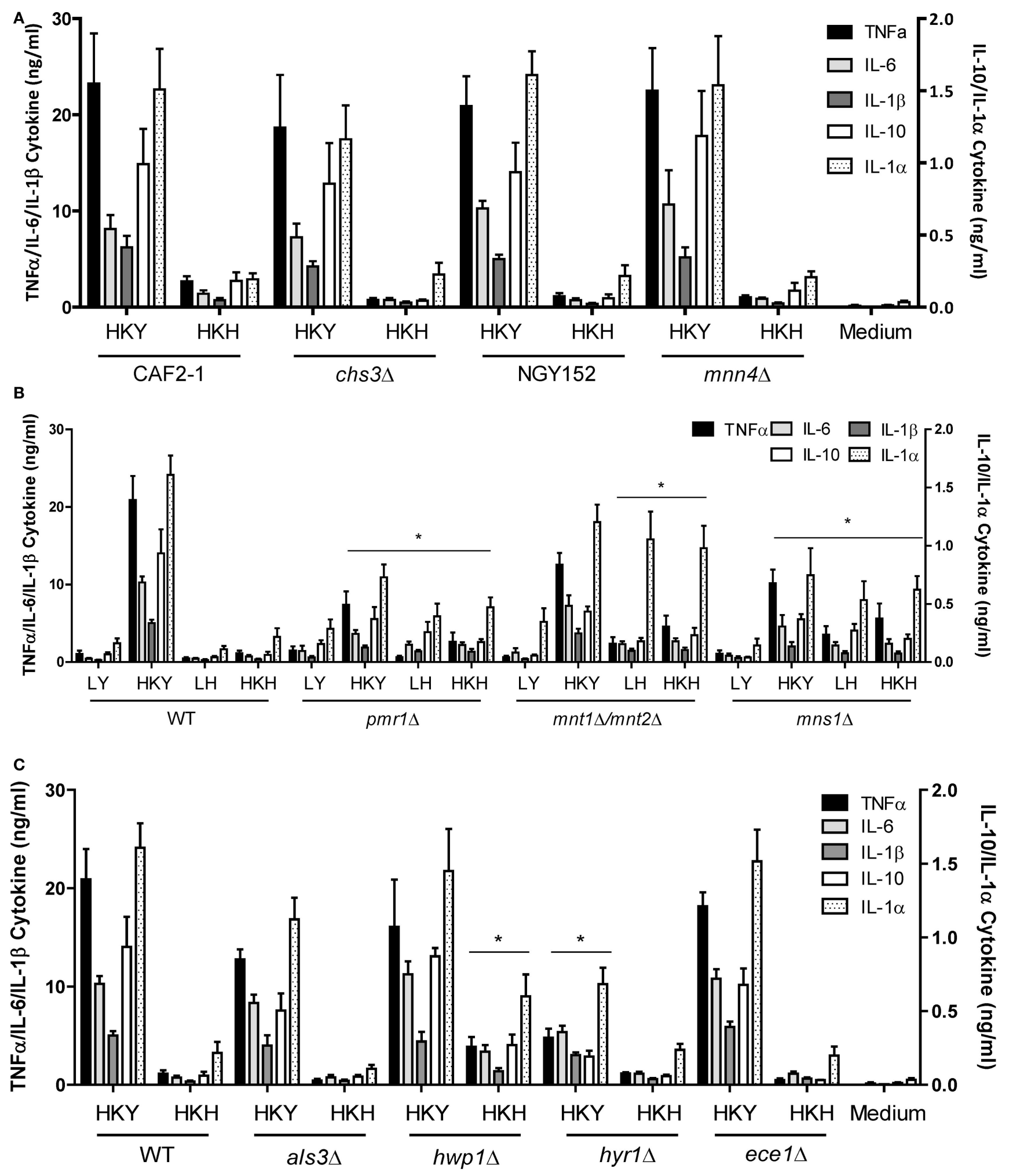

FIGURE 5 | Cytokine production stimulated by cell wall mutants of yeast and hyphal cells. (A) Cytokine production stimulated by human PBMCs with LY - live yeast; HKY - heat-killed yeast; LH-live hyphae; HKH-heat-killed hyphae; Candida albicans mnn4 $\Delta$ and chs3 $\Delta$ and control strains, NGY152 and CAF2-1. (B) Cytokine stimulation with mannosylation defective mutants, pmr1 $1 \Delta$, mnt $1 \Delta / m n t 2 \Delta$, and $m n s 1 \Delta$. (C) als $3 \Delta$, hwp $1 \Delta$, hyr $1 \Delta$, and ece1 $\Delta$. Results presented as mean \pm SEM $(n=6)$, and the asterisks indicate comparison of the wild-type values and the mutant strains $\left({ }^{*} p<0.05\right)$. 
TABLE 1 | Cell wall composition of Candida albicans strains.

\begin{tabular}{|c|c|c|c|}
\hline Strain & Glucosamine & Glucose & Mannose \\
\hline \multicolumn{4}{|c|}{ Yeast morphology } \\
\hline WT & $1.01 \pm 0.4$ & $58.31 \pm 2.25$ & $40.68 \pm 2.19$ \\
\hline hwp1s & $0.77 \pm 0.46$ & $52.99 \pm 0.77^{\star}$ & $46.24 \pm 0.34^{\star}$ \\
\hline$m n s 1 \Delta$ & $0.91 \pm 1.18$ & $88.71 \pm 2.34^{*}$ & $10.38 \pm 0.96^{\star}$ \\
\hline$p m r 1 \Delta$ & $1.50 \pm 2.05$ & $99.55 \pm 3.63^{*}$ & $0.50 \pm 1.33^{*}$ \\
\hline \multicolumn{4}{|c|}{ Hypha morphology } \\
\hline WT & $4.77 \pm 0.32^{\#}$ & $87.18 \pm 1.54^{\#}$ & $8.06 \pm 0.99^{\#}$ \\
\hline hwp1s & $5.63 \pm 0.93^{\#}$ & $83.68 \pm 2.57^{\#}$ & $10.68 \pm 1.75^{\#}$ \\
\hline$m n s 1 \Delta$ & $6.10 \pm 1.34^{\#}$ & $87.61 \pm 1.59$ & $6.29 \pm 0.18^{\#}$ \\
\hline pmr1s & $1.48 \pm 0.74^{\star}$ & $97.72 \pm 2.01^{*}$ & $0.80 \pm 0.68^{*}, \#$ \\
\hline
\end{tabular}

Means $\pm S D(n=3){ }^{*} p<0.05$ when comparing the mutant strain with the wild-type control cells.

"p $p<0.05$ when comparing hyphae with yeast cells.

PAMPs can engage collaboratively with PRRs, thus resulting in coreceptor amplification of the cytokine response (18, 60-62).

Although the hyphae used in these experiments also had a parental yeast cell, the combined cytokine signal due to the hypha plus parent yeast cell was significantly less than that expected from the yeast cell alone. This may suggest that either the yeast cell surface of germ tube matures to become different from that of a free yeast cell or that an unknown mechanism operates in germ tubes that are able to block cytokine induction due to the mother yeast cell. However, if a blocking signal is present, it does not operate in "trans" since hyphae added after free yeast cells were used to stimulate PBMCs did not interfere with the ensuing yeast cell stimulated cytokine response. Interestingly, hyphae of C. dubliniensis also stimulated less cytokine from PBMCs than yeast cells. The genomes of C. albicans and C. dubliniensis are 95\% identical, and the cell walls are also thought to be of similar composition, although there are notable differences in the cell wall proteome (63). These closely related Candida species therefore show both common aspects and some differences in the nature of the immune response to yeast and hyphal cells.

Different immune cell types respond differently to C. albicans yeast and hyphae. For example, C. albicans hyphae induce higher levels of TNF $\alpha$ than yeast cells in macrophages $(64,65)$, while yeast and hyphae stimulate comparable levels of IL- 8 cytokine by human neutrophils (47). It was shown that $C$. albicans induced different cytokine responses from oral and vaginal epithelial cells, and that hyphae induced higher cytokine levels than yeast cells in both epithelial cell types $(32,66)$. However, our findings reinforce previous studies where C. albicans filaments (hyphae and pseudohyphae) were reported to stimulate the production of less IL-12, IFN- $\gamma$, IL-1 $\beta$, and IL-12p70 by human PBMCs and murine splenic lymphocytes than C. albicans yeast cells (30, 58, 67-69). It was also previously reported that TLR4-mediated proinflammatory signals were diminished during the germination of C. albicans yeast cells into hyphae (30). Supporting this, we show that $C$. albicans cells grown at $37^{\circ} \mathrm{C}$ have a progressively reduced $\mathrm{TNF} \alpha$ cytokine response. In addition, it was reported that C. albicans hyphal cell walls also stimulated less chemokines than yeast cell walls (68), and it was suggested that this may be due to surface expression of $\beta 1,6$-glucan being lower on hyphae compared to yeast cells. The cell SA of each individual hyphal compartment is larger than that of a yeast cell, and hyphae have no bud scars where inner wall layers are exposed (29). Therefore, it is possible that the density of certain immune agonists is less concentrated on the hyphal surface than on yeast cells. Also, progressive elongation of hyphae in vivo has been shown to result in increasing exposures of $\beta 1,3$-glucan (70). Hence, cellular morphogenesis leading to filamentous growth of $C$. albicans leads to important progressive modifications of cell wall composition and architecture that has profound and differing effects on the immune response.

Cell wall polysaccharide analysis showed that yeast cell walls contained significantly higher amounts of mannan but lower amounts chitin and glucan compared to that of hyphal cell walls (Table 1). The reduction of mannan and increase in chitin content of hyphal cell walls might also be related to the lower cytokine responses to $C$. albicans hyphae $(28,45,71,72)$. Our results underline the importance of $\mathrm{N}$ - and $\mathrm{O}$-linked mannans in the recognition of $C$. albicans hyphae by human PBMCs (Figure 5) since $N$ - and $O$-mannan mutants $(45,52)$, but not chitin and phosphomannan mutants, stimulated the production of higher levels of cytokines that wild-type hyphae.

Although the primary polysaccharides in the cell wall are likely to have a major influence on immune recognition, it was noted that a HK $h w p 1 \Delta$ cell wall protein deletion mutant induced an increased cytokine signal, despite having no measurable alteration in hyphal mannan or glucan content. Similarly, a mutant lacking MNS1 grown under hyphal-inducing conditions showed insignificant changes in cell wall components, but substantial reduction in cytokine production. However, the $m n s 1$ yeast cells had $34 \%$ increased glucan as a compensation of $70 \%$ reduction in mannan, and a reduced cytokine profile. Therefore, there was no direct or universal correlation between cytokine induction and gross cell wall polysaccharide composition.

Our observations suggest that surface proteins, polysaccharides, and virulence factors are regulated or modified during filamentous growth resulting in changes in the immune response. Such changes in the incorporation of surface cell wall proteins on cells of different morphology could mask or unmask PAMPs, thereby blocking or promoting PRR engagement.

The presence of $C$. albicans hyphae could potentially compete with yeast cells for the ability to bind PRRs and stimulate immune cells. This would be important if specific yeast cell wall proteins are important for immune recognition and activation. We observed that a pga29 mutant grown in the yeast form stimulated less TNF $\alpha$ from human PBMCs. This cell wall protein Pga29 has homologs in several pathogenic Candida spp. and is abundant in yeast cell walls in C. albicans but not in hyphae (73). Deletion of PGA29 resulted in decreased glucan-mannan in the cell wall, and reduction of TNF $\alpha$, IL- 6 , and IL- 8 stimulated by oral reconstituted human epithelial cells (74). Therefore, both yeast and hypha-specific cell wall proteins may directly modulate immune responses.

It is also possible that $C$. albicans hyphal cells may produce secreted molecules that suppress immune recognition. Quorumsensing molecules, such as farnesol, tyrosol, phenylethanol, and tryptophol, produced by $C$. albicans, play a key role in morphogenesis (75-77), and tyrosol acts negatively on cytokine production stimulated by RAW 264.7 macrophages induced 


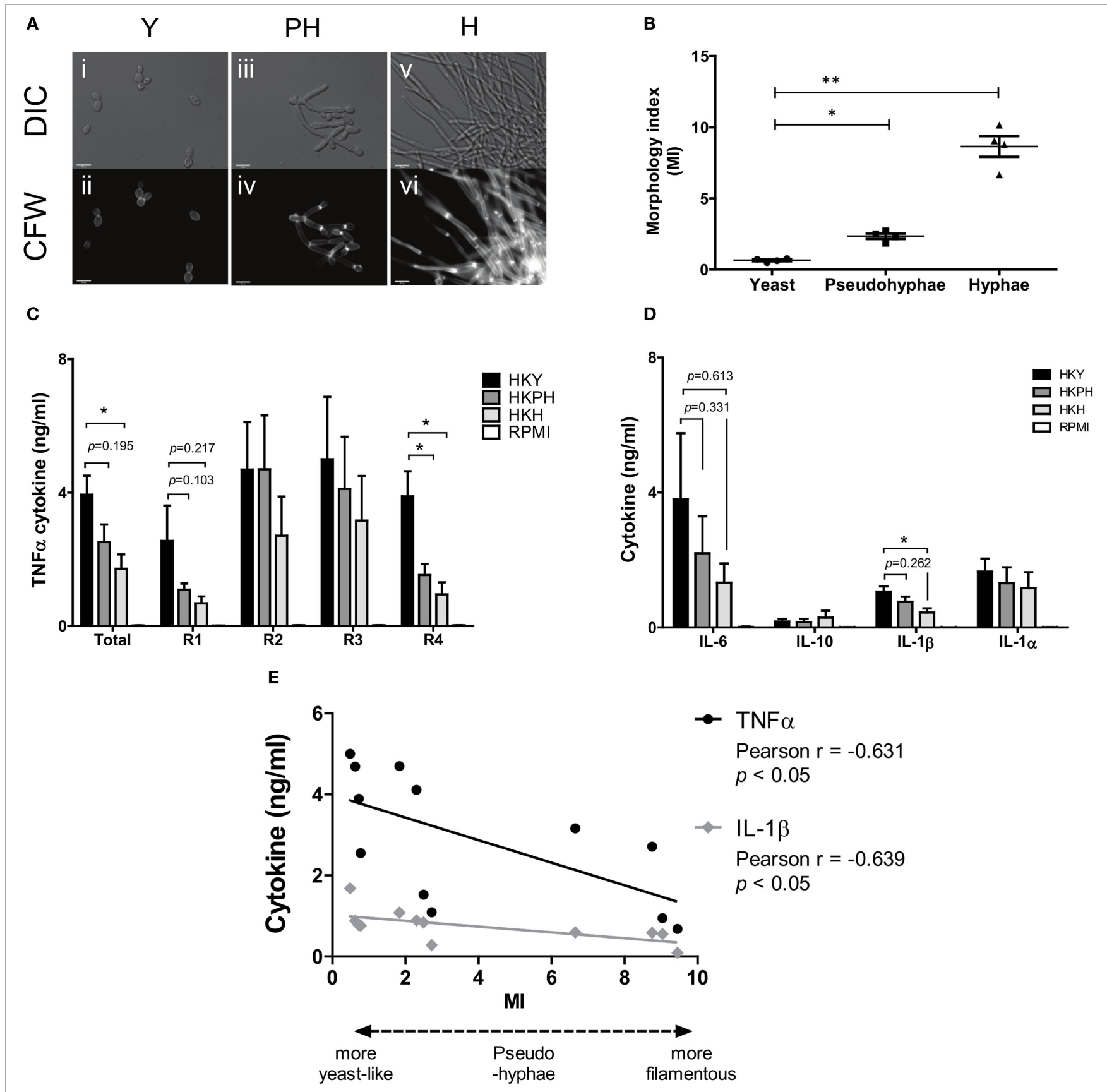

FIGURE 6 | Cytokine production by hPBMCs stimulated by different Candida albicans morphological forms. (A) Yeasts (i-ii), pseudohyphae (iii-iv), or hyphae (v-vi) of C. albicans NGY152 were grown in RPMI 1640 (pH 7) for 6 h at 25, 30, and $37^{\circ} \mathrm{C}$, respectively, fixed, and stained with $25 \mu \mathrm{g} / \mathrm{ml} \mathrm{CFW}$ to visualize the cell wall. Scale bars $=10 \mu \mathrm{m}$. (B) Morphological index (MI) of yeast, pseudohyphal, and hyphal cells was measured. Error bars are SEMs (averages from 50 cell measurements and 4 biological replicates) ( ${ }^{\star} p<0.05$; $\left.{ }^{\star \star} p<0.01\right)$. (C) TNF $\alpha$ cytokine production elicited by human peripheral blood mononuclear cells (PBMCs) with HK NGY152 of yeast $(Y)$, pseudohypha $(\mathrm{PH})$, and hypha $(\mathrm{H})$ cells. Each replicate $(\mathrm{R} 1-\mathrm{R} 4)$ were averaged as total values. Data are means $\pm \mathrm{SEM}\left(n>6\right.$; $\left.{ }^{\star} p<0.05\right)$.

(D) IL-6, IL-1 $\beta, I L-1 \alpha$, and IL-10 cytokine production elicited by human PBMCs with HK of yeast (Y), pseudohypha (PH), and hypha (H) cells. Data are means \pm SEM $\left(n>6\right.$; $\left.{ }^{*} p<0.05\right)$. (E) Correlation between TNF $\alpha$ or IL-1 $\beta$ cytokine and Ml. Results are Person $R$ values $(n=4$ biological replica).

by lipopolysaccharide (78). However, we showed that neither live nor HK hyphae could suppress yeast cell-induced cytokine production in trans; therefore, soluble factors were not suggested as playing a significant role in our experiments.
Our observations and those of previous studies (30, 58, $68,69)$ demonstrate that C. albicans hyphae stimulated lower cytokine production by PBMCs than C. albicans yeast cells, thus indicating that C. albicans hyphae may help to evade or 
alter the host immune response. However, it is clear that $C$. albicans hyphae induced strong cytokine responses and caused more damage to epithelial cells, while yeast cells did not trigger cytokine responses $(66,79,80)$. Also, C. albicans hyphae induce stronger cytokine responses that yeast cells from macrophages $(64,65)$. The common denominator of these various reports is that cellular morphogenesis plays an important role in determining the immune response to $C$. albicans, but the nature of this response is both host cell type specific and pathogen morphotype dependent. These data underline the perspective that $C$. albicans presents a moving target to the cells of the innate immune response.

\section{ETHICS STATEMENT}

Blood samples were used in this study to generate human peripheral blood monocytes. Samples were collected from healthy volunteers according to local guidelines and regulations, as approved by the College Ethics Review Board of the University of Aberdeen (CERB/2012/11/676).

\section{AUTHOR CONTRIBUTIONS}

LM and KL performed experiments. NG, HM-M, LM, and KL conceived and designed experiments and analyzed the data. NG and HM-M supervised the project. LM, KL, and NG contributed to writing of the manuscript. All the authors reviewed the manuscript.

\section{ACKNOWLEDGMENTS}

The authors thank Amy Whittington for preliminary experiments on in vitro induction of pseudohyphae and Mihai Netea for discussions. The authors also thank Michael Weig for the pga29 strains.

\section{REFERENCES}

1. Gudlaugsson O, Gillespie S, Lee K, Vande Berg J, Hu J, Messer S, et al. Attributable mortality of nosocomial candidemia, revisited. Clin Infect Dis (2003) 37:1172-7. doi:10.1086/378745

2. Pappas PG, Rex JH, Lee J, Hamill RJ, Larsen RA, Powderly W, et al. A prospective observational study of candidemia: epidemiology, therapy, and influences on mortality in hospitalized adult and pediatric patients. Clin Infect Dis (2003) 37:634-43. doi:10.1086/376906

3. Kullberg BJ, Arendrup MC. Invasive candidiasis. N Engl J Med (2015) 373:1445-56. doi:10.1056/NEJMra1315399

4. Erwig LP, Gow NAR. Interactions of fungal pathogens with phagocytes. Nat Rev Microbiol (2016) 14:163-76. doi:10.1038/nrmicro.2015.21

5. Sudbery PE, Gow NAR, Berman J. The distinct morphogenic states of Candida albicans. Trends Microbiol (2004) 12:317-24. doi:10.1016/j.tim.2004.05.008

6. Gow NAR, van de Veerdonk FL, Brown AJP, Netea MG. Candida albicans morphogenesis and host defence: discriminating invasion from colonization. Nat Rev Microbiol (2011) 10:112-22. doi:10.1038/nrmicro2711

7. Sudbery PE. Growth of Candida albicans hyphae. Nat Rev Microbiol (2011) 9:737-48. doi:10.1038/nrmicro2636

8. Gow NAR, Hube B. Importance of the Candida albicans cell wall during commensalism and infection. Curr Opin Microbiol (2012) 15:406-12. doi:10.1016/ j.mib.2012.04.005

9. Kullberg BJ, Arendrup MC. Invasive candidiasis. N Engl J Med (2016) 374:793-5. doi:10.1056/NEJMc1514201

\section{FUNDING}

NG and AW were supported by the Wellcome Trust (086827, 075470, 097377, 101873, and 200208); the European Union ALLFUN (FP7/2007 2013, HEALTH-2010-260338), and the MRC Centre for Medical Mycology for funding (N006364/1). LM was supported by a SORSAS (Scottish Overseas Research Students Award Scheme) from the University of Aberdeen and Funding from the Rwandan Government.

\section{SUPPLEMENTARY MATERIAL}

The Supplementary Material for this article can be found online at http://journal.frontiersin.org/article/10.3389/fimmu. 2017.00629/full\#supplementary-material.

FIGURE S1 | Cell damage assay of hPBMC stimulated with Candida albicans. Lactate dehydrogenase activity released from $5 \times 10^{5} \mathrm{hPBMCs}$ into the culture medium was determined after $24 \mathrm{~h}$ stimulated with either C. albicans heat-killed yeast or $\mathrm{HKH}$ at the different number of cells from $1 \times 10^{2}$ to $1 \times 10^{6}$ cells. The result represented as a percentage relative to $100 \%$ cell death of hPBMCs when killed with $2 \%$ Triton-X-100. Error bars = SEM $(n=4)$.

FIGURE S2 | Cytokine production by hPBMCs stimulated by different Candida albicans coincubated with toll-like receptors (TLRs) ligands. Human peripheral blood mononuclear cells were stimulated using a mixture of C. albicans cells and TLRs ligands. Cells were either live $(L)$ or heat-killed (HK), and yeast $(\mathrm{Y}$ ) or hyphae $(\mathrm{H})$. TLRs ligands used were flagellin (for TLR5), LPS (for TLR4), $\mathrm{Pam}_{3} \mathrm{CSK}_{4}$ (for TLR2/TLR1), zymosan, and curdlan (for Dectin-1). The cytokines measured were TNF- $\alpha$ (A), IL-6 (B), IL-1 $\beta$ (C), IL-1 $\alpha$ (D), and IL-10 (E). IL-10 was barely detectable and could not be evaluated. Data are means \pm SEM $\left(n>3 ;{ }^{*} p<0.05\right)$. ND, not detectable.

FIGURE S3 | TNF $\alpha$ cytokine production by hPBMCs incubated with Candida albicans lacking PGA29. C. albicans cells lacking PGA29 was grown in RPMl $1640+2.5 \%$ fetal calf serum at 25 or $37^{\circ} \mathrm{C}$ for $3.5 \mathrm{~h}$. Cells were collected and heat killed. The mutant was incubated with hPBMCs for $24 \mathrm{~h}$. Then, TNF $\alpha$ cytokine production was determined (see Methods and Materials). Data are means \pm SEM $\left(n>9 ;{ }^{*} p<0.05 ;{ }^{* \star *} p<0.001\right)$

TABLE S1 | C. albicans and other fungal strains used in this study.

10. Sellam A, Whiteway M. Recent advances on Candida albicans biology and virulence. F1000Res (2016) 5:2582. doi:10.12688/f1000research.9617.1

11. Netea MG, Brown GD, Kullberg BJ, Gow NAR. An integrated model of the recognition of Candida albicans by the innate immune system. Nat Rev Microbiol (2008) 6:67-78. doi:10.1038/nrmicro1815

12. Hoebe K, Janssen E, Beutler B. The interface between innate and adaptive immunity. Nat Immunol (2004) 5:971-4. doi:10.1038/ni1004-971

13. Medzhitov R. Recognition of microorganisms and activation of the immune response. Nature (2007) 449:819-26. doi:10.1038/nature06246

14. Cheng SC, Joosten LA, Kullberg BJ, Netea MG. Interplay between Candida albicans and the mammalian innate host defense. Infect Immun (2012) 80:1304-13. doi:10.1128/IAI.06146-11

15. Netea MG, Joosten LA, van der Meer JW, Kullberg BJ, van de Veerdonk FL. Immune defence against Candida fungal infections. Nat Rev Immunol (2015) 15:630-42. doi:10.1038/nri3897

16. Gow NAR, Netea MG. Medical mycology and fungal immunology: new research perspectives addressing a major world health challenge. Philos Trans R Soc Lond B Biol Sci (2016) 371. doi:10.1098/rstb.2015.0462

17. Netea MG, Gow NAR, Munro CA, Bates S, Collins C, Ferwerda G, et al. Immune sensing of Candida albicans requires cooperative recognition of mannans and glucans by lectin and toll-like receptors. J Clin Invest (2006) 116:1642-50. doi:10.1172/JCI27114

18. Gow NAR, Netea MG, Munro CA, Ferwerda G, Bates S, Mora-Montes HM, et al. Immune recognition of Candida albicans beta-glucan by dectin-1. J Infect Dis (2007) 196:1565-71. doi:10.1086/523110 
19. Cambi A, Netea MG, Mora-Montes HM, Gow NAR, Hato SV, Lowman DW, et al. Dendritic cell interaction with Candida albicans critically depends on $N$-linked mannan. J Biol Chem (2008) 283:20590-9. doi:10.1074/jbc. M709334200

20. Heinsbroek SEM, Taylor PR, Martinez FO, Martinez-Pomares L, Brown GD, Gordon S. Stage-specific sampling by pattern recognition receptors during Candida albicans phagocytosis. PLoS Pathog (2008) 4:e1000218. doi:10.1371/ journal.ppat.1000218

21. McKenzie CGJ, Koser U, Lewis LE, Bain JM, Mora-Montes HM, Barker RN, et al. Contribution of Candida albicans cell wall components to recognition by and escape from murine macrophages. Infect Immun (2010) 78:1650-8. doi:10.1128/IAI.00001-10

22. Jouault T, El Abed-El Behi M, Martínez-Esparza M, Breuilh L, Trinel PA, Chamaillard M, et al. Specific recognition of Candida albicans by macrophages requires galectin-3 to discriminate Saccharomyces cerevisiae and needs association with TLR2 for signaling. J Immunol (2006) 177:4679-87. doi:10.4049/ jimmunol.177.7.4679

23. Kohatsu L, Hsu DK, Jegalian AG, Liu FT, Baum LG. Galectin-3 induces death of Candida species expressing specific beta-1,2-linked mannans. J Immunol (2006) 177:4718-26. doi:10.4049/jimmunol.177.7.4718

24. Linden JR, De Paepe ME, Laforce-Nesbitt SS, Bliss JM. Galectin-3 plays an important role in protection against disseminated candidiasis. Med Mycol (2013) 51:641-51. doi:10.3109/13693786.2013.770607

25. Courjol F, Jouault T, Mille C, Hall R, Maes E, Sendid B, et al. Beta-1,2mannosyltransferases 1 and 3 participate in yeast and hyphae $O$ - and $N$-linked mannosylation and alter Candida albicans fitness during infection. Open Forum Infect Dis (2015) 2:ofv116. doi:10.1093/ofid/ofv116

26. Harris M, Mora-Montes HM, Gow NAR, Coote PJ. Loss of mannosylphosphate from Candida albicans cell wall proteins results in enhanced resistance to the inhibitory effect of a cationic antimicrobial peptide via reduced peptide binding to the cell surface. Microbiology (2009) 155:1058-70. doi:10.1099/ mic. $0.026120-0$

27. Rubin-Bejerano I, Abeijon C, Magnelli P, Grisafi P, Fink GR. Phagocytosis by human neutrophils is stimulated by a unique fungal cell wall component. Cell Host Microbe (2007) 2:55-67. doi:10.1016/j.chom.2007.06.002

28. Wagener J, Malireddi RKS, Lenardon MD, Köberle M, Vautier S, MacCallum DM, et al. Fungal chitin dampens inflammation through IL-10 induction mediated by NOD2 and TLR9 activation. PLoS Pathog (2014) 10. doi:10.1371/journal.ppat.1004050

29. Gantner BN, Simmons RM, Underhill DM. Dectin-1 mediates macrophage recognition of Candida albicans yeast but not filaments. EMBO J (2005) 24:1277-86. doi:10.1038/sj.emboj.7600594

30. Van Der Graaf CAA, Netea MG, Verschueren I, Van Der Meer JWM, Kullberg BJ. Differential cytokine production and toll-like receptor signaling pathways by Candida albicans blastoconidia and hyphae. Infect Immun (2005) 73:7458-64. doi:10.1128/IAI.73.11.7458-7464.2005

31. Cheng SC, van de Veerdonk FL, Lenardon M, Stoffels M, Plantinga T, Smeekens S, et al. The dectin-1/inflammasome pathway is responsible for the induction of protective T-helper 17 responses that discriminate between yeasts and hyphae of Candida albicans. JLeukoc Biol (2011) 90:357-66. doi:10.1189/jlb.1210702

32. Moyes DL, Murciano C, Runglall M, Islam A, Thavaraj S, Naglik JR. Candida albicans yeast and hyphae are discriminated by MAPK signaling in vaginal epithelial cells. PLoS One (2011) 6:e26580. doi:10.1371/journal. pone. 0026580

33. Lo HJ, Köhler JR, Didomenico B, Loebenberg D, Cacciapuoti A, Fink GR. Nonfilamentous C. albicans mutants are avirulent. Cell (1997) 90:939-49. doi:10.1016/S0092-8674(00)80358-X

34. Gow NAR, Brown AJP, Odds FC. Fungal morphogenesis and host invasion. Curr Opin Microbiol (2002) 5:366-71. doi:10.1016/S1369-5274(02)00338-7

35. Moyes DL, Wilson D, Richardson JP, Mogavero S, Tang SX, Wernecke J, et al. Candidalysin is a fungal peptide toxin critical for mucosal infection. Nature (2016) 532:64-8. doi:10.1038/nature17625

36. Ghannoum MA, Spellberg B, Saporito-Irwin SM, Fonzi WA. Reduced virulence of Candida albicans PHR1 mutants. Infect Immun (1995) 63:4528-30.

37. Calera JA, Zhao XJ, Calderone R. Defective hyphal development and avirulence caused by a deletion of the SSK1 response regulator gene in Candida albicans. Infect Immun (2000) 68:518-25. doi:10.1128/ IAI.68.2.518-525.2000

38. Murad AMA, Leng P, Straffon M, Wishart J, Macaskill S, MacCallum D, et al. NRG1 represses yeast-hypha morphogenesis and hypha-specific gene expression in Candida albicans. EMBO J (2001) 20:4742-52. doi:10.1093/ emboj/20.17.4742

39. Saville SP, Lazzell AL, Monteagudo C, Lopez-Ribot JL. Engineered control of cell morphology in vivo reveals distinct roles for yeast and filamentous forms of Candida albicans during infection. Eukaryot Cell (2003) 2:1053-60. doi:10.1128/EC.2.5.1053-1060.2003

40. Zheng X, Wang Y, Wang Y. Hgcl, a novel hypha-specific G1 cyclin-related protein regulates Candida albicans hyphal morphogenesis. EMBO J (2004) 23:1845-56. doi:10.1038/sj.emboj.7600195

41. Merson-Davies LA, Odds FC. A morphology index for characterization of cell shape in Candida albicans. J Gen Microbiol (1989) 135:3143-52.

42. Berman J, Gow NAR. Chapter 3. Cell cycle of fungal pathogens. In: San-Blas G, Calderone RA, editors. Pathogenic Fungi: Structural Biology and Taxonomy. Norfolk, UK: Caster Academic Press (2004). p. 101-25.

43. Lee KL, Buckley HR, Campbell CC. An amino acid liquid synthetic medium for the development of mycelial and yeast forms of Candida albicans. Sabouraudia (1975) 13:148-53. doi:10.1080/00362177585190271

44. Endres S, Ghorbani R, Lonnemann G, van der Meer JWM, Dinarello CA. Measurement of immunoreactive interleukin- $1 \beta$ from human mononuclear cells: optimization of recovery, intrasubject consistency, and comparison with interleukin-1a and tumor necrosis factor. Clin Immunol Immunopathol (1988) 49:424-38. doi:10.1016/0090-1229(88)90130-4

45. Mora-Montes HM, Bates S, Netea MG, Diaz-Jimenez DF, Lopez-Romero E, Zinker S, et al. Endoplasmic reticulum alpha-glycosidases of Candida albicans are required for $\mathrm{N}$ glycosylation, cell wall integrity, and normal host-fungus interaction. Eukaryot Cell (2007) 6:2184-93. doi:10.1128/EC. 00350-07

46. Plaine A, Walker L, Da Costa G, Mora-Montes HM, McKinnon A, Gow NA, et al. Functional analysis of Candida albicans GPI-anchored proteins: roles in cell wall integrity and caspofungin sensitivity. Fungal Genet Biol (2008) 45:1404-14. doi:10.1016/j.fgb.2008.08.003

47. Hosseinzadeh A, Urban CF. Novel insight into neutrophil immune responses by dry mass determination of Candida albicans morphotypes. PLoS One (2013) 8:e77993. doi:10.1371/journal.pone.0077993

48. Fidel PL Jr, Vazquez JA, Sobel JD. Candida glabrata: review of epidemiology, pathogenesis, and clinical disease with comparison to C. albicans. Clin Microbiol Rev (1999) 12:80-96.

49. Bulawa CE, Miller DW, Henry LK, Becker JM. Attenuated virulence of chitin-deficient mutants of Candida albicans. Proc Natl Acad Sci U S A (1995) 92:10570-4. doi:10.1073/pnas.92.23.10570

50. Hobson RP, Munro CA, Bates S, MacCallum DM, Cutler JE, Heinsbroek SE, et al. Loss of cell wall mannosylphosphate in Candida albicans does not influence macrophage recognition. J Biol Chem (2004) 279:39628-35. doi:10.1074/ jbc.M405003200

51. Bates S, MacCallum DM, Bertram G, Munro CA, Hughes HB, Buurman ET, et al. Candida albicans Pmrlp, a secretory pathway P-type $\mathrm{Ca}^{2+} / \mathrm{Mn}^{2+}$-ATPase, is required for glycosylation and virulence. J Biol Chem (2005) 280:23408-15. doi:10.1074/jbc.M502162200

52. Munro CA, Bates S, Buurman ET, Hughes HB, Maccallum DM, Bertram G, et al. Mnt1p and Mnt2p of Candida albicans are partially redundant alpha-1,2-mannosyltransferases that participate in $O$-linked mannosylation and are required for adhesion and virulence. J Biol Chem (2005) 280:1051-60. doi:10.1074/ jbc.M411413200

53. Zhao X, Oh SH, Cheng G, Green CB, Nuessen JA, Yeater K, et al. ALS3 and ALS8 represent a single locus that encodes a Candida albicans adhesin; functional comparisons between Als3p and Alslp. Microbiology (2004) 150:2415-28. doi:10.1099/mic.0.26943-0

54. Sundstrom P, Balish E, Allen CM. Essential role of the Candida albicans transglutaminase substrate, hyphal wall protein 1 , in lethal oroesophageal candidiasis in immunodeficient mice. J Infect Dis (2002) 185:521-30. doi: $10.1086 / 338836$

55. Bailey DA, Feldmann PJF, Bovey M, Gow NAR, Brown AJP. The Candida albicans HYR1 gene, which is activated in response to hyphal development, 
belongs to a gene family encoding yeast cell wall proteins. J Bacteriol (1996) 178:5353-60. doi:10.1128/jb.178.18.5353-5360.1996

56. Birse CE, Irwin MY, Fonzi WA, Sypherd PS. Cloning and characterization of $E C E 1$, a gene expressed in association with cell elongation of the dimorphic pathogen Candida albicans. Infect Immun (1993) 61:3648-55.

57. Hornby JM, Dumitru R, Nickerson KW. High phosphate (up to $600 \mathrm{mM}$ ) induces pseudohyphal development in five wild type Candida albicans. J Microbiol Methods (2004) 56:119-24. doi:10.1016/j.mimet.2003.09.021

58. Chiani P, Bromuro C, Torosantucci A. Defective induction of interleukin-12 in human monocytes by germ-tube forms of Candida albicans. Infect Immun (2000) 68:5628-34. doi:10.1128/IAI.68.10.5628-5634.2000

59. Beaussart A, Alsteens D, El-Kirat-Chatel S, Lipke PN, Kucharíková S, Van Dijck P, et al. Single-molecule imaging and functional analysis of Als adhesins and mannans during Candida albicans morphogenesis. ACS Nano (2012) 6:10950-64. doi:10.1021/nn304505s

60. Brown GD, Herre J, Williams DL, Willment JA, Marshall ASJ, Gordon S. Dectin-1 mediates the biological effects of ß-glucans. J Exp Med (2003) 197:1119-24. doi:10.1084/jem.20021890

61. Gantner BN, Simmons RM, Canavera SJ, Akira S, Underhill DM. Collaborative induction of inflammatory responses by dectin-1 and toll-like receptor 2 . J Exp Med (2003) 197:1107-17. doi:10.1084/jem.20021787

62. Dennehy KM, Willment JA, Williams DL, Brown GD. Reciprocal regulation of IL-23 and IL-12 following co-activation of Dectin-1 and TLR signaling pathways. Eur J Immunol (2009) 39:1379-86. doi:10.1002/eji.200838543

63. Jackson AP, Gamble JA, Yeomans T, Moran GP, Saunders D, Harris D, et al. Comparative genomics of the fungal pathogens Candida dubliniensis and Candida albicans. Genome Res (2009) 19:2231-44. doi:10.1101/ gr.097501.109

64. Blasi E, Pitzurra L, Puliti M, Bartoli A, Bistoni F. Candida albicans hyphal form enhances tumor necrosis factor mRNA levels and protein secretion in murine ANA-1 macrophages. Cell Immunol (1992) 142:137-44. doi:10.1016/0008-8749(92)90275-T

65. Matuschak GM, Lechner AJ. The yeast to hyphal transition following hematogenous candidiasis induces shock and organ injury independent of circulating tumor necrosis factor-alpha. Crit Care Med (1997) 25:111-20. doi:10.1097/00003246-199701000-00022

66. Moyes DL, Runglall M, Murciano C, Shen C, Nayar D, Thavaraj S, et al. A biphasic innate immune MAPK response discriminates between the yeast and hyphal forms of Candida albicans in epithelial cells. Cell Host Microbe (2010) 8:225-35. doi:10.1016/j.chom.2010.08.002

67. d'Ostiani CF, Del Sero G, Bacci A, Montagnoli C, Spreca A, Mencacci A, et al. Dendritic cells discriminate between yeasts and hyphae of the fungus Candida albicans. Implications for initiation of T helper cell immunity in vitro and in vivo. J Exp Med (2000) 191:1661-74. doi:10.1084/jem.191.10.1661

68. Torosantucci A, Chiani P, Cassone A. Differential chemokine response of human monocytes to yeast and hyphal forms of Candida albicans and its relation to the B-1,6 glucan of the fungal cell wall. J Leukoc Biol (2000) 68(6):923-32.

69. Van De Veerdonk FL, Joosten LAB, Devesa I, Héctor MM, Kanneganti T, Dinarello CA, et al. Bypassing pathogen-induced inflammasome activation for the regulation of interleukin-1ß production by the fungal pathogen Candida albicans. J Infect Dis (2009) 199:1087-96. doi:10.1086/597274

70. Wheeler RT, Kombe D, Agarwala SD, Fink GR. Dynamic, morphotypespecific Candida albicans $\beta$-glucan exposure during infection and drug treatment. PLoS Pathog (2008) 4:e1000227. doi:10.1371/journal.ppat.1000227

71. Bates S, De La Rosa JM, MacCallum DM, Brown AJP, Gow NAR, Odds FC. Candida albicans Iff11, a secreted protein required for cell wall structure and virulence. Infect Immun (2007) 75:2922-8. doi:10.1128/IAI.00102-07

72. Mora-MontesHM,NeteaMG,FerwerdaG,LenardonMD,BrownGD,MisuraAS, et al. Recognition and blocking of innate immunity cells by Candida albicans chitin. Infect Immun (2011) 79:1961-70. doi:10.1128/IAI.01282-10

73. De Boer AD, De Groot PWJ, Weindl G, Schaller M, Riedel D, Diez-Orejas R, et al. The Candida albicans cell wall protein Rhd3/Pga29 is abundant in the yeast form and contributes to virulence. Yeast (2010) 27:611-24. doi:10.1002/ yea. 1790

74. Vavala E, Mignogna G, Spano F, Stringaro A, Colone M, Sanguinetti M, et al. The cell wall protein Rhd3/Pga29 is over-expressed in Candida albicans upon micafungin treatment. J Chemother (2013) 25:332-40. doi:10.1179/19739478 13Y.0000000091

75. HornbyJM, Jensen EC, Lisec AD, Tasto JJ, Jahnke B, Shoemaker R, etal. Quorum sensing in the dimorphic fungus Candida albicans is mediated by farnesol. Appl Environ Microbiol (2001) 67:2982-92. doi:10.1128/AEM.67.7.29822992.2001

76. Chen H, Fujita M, Feng Q, Clardy J, Fink GR. Tyrosol is a quorum-sensing molecule in Candida albicans. Proc Natl Acad Sci U S A (2004) 101:5048-52. doi:10.1073/pnas.0401416101

77. Chen H, Fink GR. Feedback control of morphogenesis in fungi by aromatic alcohols. Genes Dev (2006) 20:1150-61. doi:10.1101/gad.1411806

78. Lu J, Huang G, Wang Z, Zhuang S, Xu L, Song B, et al. Tyrosol exhibits negative regulatory effects on LPS response and endotoxemia. Food Chem Toxicol (2013) 62:172-8. doi:10.1016/j.fct.2013.08.031

79. Dalle F, Wächtler B, L'Ollivier C, Holland G, Bannert N, Wilson D, et al. Cellular interactions of Candida albicans with human oral epithelial cells and enterocytes. Cell Microbiol (2010) 12:248-71. doi:10.1111/j.1462-5822.2009.01394.x

80. Moyes DL, Murciano C, Runglall M, Kohli A, Islam A, Naglik JR. Activation of MAPK/c-Fos induced responses in oral epithelial cells is specific to Candida albicans and Candida dubliniensis hyphae. Med Microbiol Immunol (2012) 201:93-101. doi:10.1007/s00430-011-0209-y

Conflict of Interest Statement: The authors declare that the research was conducted in the absence of any commercial or financial relationships that could be construed as a potential conflict of interest.

Copyright () 2017 Mukaremera, Lee, Mora-Montes and Gow. This is an openaccess article distributed under the terms of the Creative Commons Attribution License (CC BY). The use, distribution or reproduction in other forums is permitted, provided the original author(s) or licensor are credited and that the original publication in this journal is cited, in accordance with accepted academic practice. No use, distribution or reproduction is permitted which does not comply with these terms. 